Article

\title{
Air Enthalpy as an IAQ Indicator in Hot and Humid Environment-Experimental Evaluation
}

\author{
Michał Piasecki ${ }^{1, *} \mathbb{C}$, Krystyna Kostyrko ${ }^{1}$, Małgorzata Fedorczak-Cisak ${ }^{2} \mathbb{1}$ and \\ Katarzyna Nowak ${ }^{2}$ \\ 1 Building Research Institute, Filtrowa 1, 00-611 Warszawa, Poland; k.kostyrko@itb.pl \\ 2 Faculty of Civil Engineering, Cracow University of Technology, 24 Warszawska Street, 31-150 Krakow, \\ Poland; mfedorczak-cisak@pk.edu.pl (M.F.-C.); knowak@pk.edu.pl (K.N.) \\ * Correspondence: m.piasecki@itb.pl; Tel.: +48-22-5664-352
}

Received: 17 February 2020; Accepted: 16 March 2020; Published: 20 March 2020

check for updates

\begin{abstract}
The authors studied the impact of indoor air humidity in the range of $60 \%$ to $90 \%$ on building user perception in the temperature range of 26 to $28^{\circ} \mathrm{C}$. The research thesis was put forward that the impact of humidity on indoor air quality dissatisfaction of building users in a warm and humid indoor environment is greater than that indicated in thermal comfort models. The presented experiment examined the indoor air quality perception of $n=28$ subjects in the test chamber of a nearly zero energy building under ten environmental conditions, together with a thermal comfort assessment. The authors developed an experimental relation for predicting building users' satisfaction based on the Weber-Fechner law, where the predicted percentage of dissatisfied users $(P D)$ is determined by means of air enthalpy $(h), P D=\mathrm{f}(h)$. The obtained results confirmed the sated thesis. Additionally, the intersection points of the experimental function and isotherms resulting from the Fanger model are presented, where the thermal comfort assessment starts to indicate lower user dissatisfaction results than experimental values. The authors recommend the experimental equation for humid air enthalpies in the range of 50 to $90 \mathrm{~kJ} / \mathrm{kg}$. The indoor air quality assessment based on the enthalpy value is simple and can be used to determine the overall Indoor Environmental Quality index of a building (IEQ index $_{\text {) }}$.
\end{abstract}

Keywords: indoor air quality; IAQ; enthalpy; humidity; thermal comfort; TC; dissatisfaction; panel tests; nearly zero energy building; NZEB; indoor environmental quality; IEQ

\section{Introduction}

\subsection{Literature Review}

People are constantly exposed to the indoor environment of buildings, which is crucial for human thermoregulation and respiratory process; consequently, people's reactions reflect the level of indoor air parameters. The impact of the indoor environment is responsible for people's health, psychophysical state and influences behavioural change, concentration and work efficiency. As early as 1936, Yaglou [1] considered the effect of temperature and humidity on people in a study for American Society of Heating, Refrigerating and Air Conditioning Engineers (ASHRAE) on ventilation requirements. To date, both parameters are considered to be the most important elements impacting the satisfaction of building users. Strategies based on the physical measurements of the indoor environment allow to take the necessary steps to ensure adequate indoor human comfort [2]. Since the beginning of the twentieth century, many environmental variables such as temperature, black ball temperature, relative humidity, air velocity, radiation and others have helped determine various indoor thermal comfort indicators [3]. Each variable, however, can show a dominant effect in certain situations, not necessarily 
additive or linear. For example, humidity is indicated as a determinant of user satisfaction in hot and humid environments [4]. There are differences between the values selected by various authors as comfort conditions and the indicators used, e.g., operative temperature and humidity, effective temperature $\left(\mathrm{ET}^{*}\right)$, Standard Effective Temperature (SET*), as well as black globe probe and humidity, black globe humidity index [5] and others. Also, the final parameters expressing the comfort of users due to the temperature and humidity in rooms in various publications are different. These include: thermal sensation vote (TSV), predicted mean vote (PMV), humidity sensation vote (HSV), thermal comfort index (TC), thermal comfort vote (TCV), thermal/humidity acceptance (THAV), percentage dissatisfied $(P D)$, perceived indoor quality (PAQ), indoor air acceptability $(A C C)$ and indoor air quality index $(I A Q)$. The authors, like most researchers, tend to express building comfort parameters in \% of satisfaction. The difficulty in transferring theoretical models to real conditions in nearly zero energy buildings (NZEB) creates a constant need to validate various comfort models taking into account very specific parameters of building, indoor condition specifications and scenarios of use [6].

The impact of humidity on human thermal and indoor air quality perception in hot and humid environments has been studied in several works in the previous years with various parameters and indicators. The use of enthalpy in studies of indoor perceptions has been carried out so far by using two main separate approaches. Most scientists have focused on the effects of temperature and humidity on people's thermal perception, where enthalpy was only a side indicator. Other researchers have analysed the direct impact of humidity and temperature on air quality perception. In fact, any research known to us did not study these two perception effects simultaneously in NZEBs with determination of the applicability ranges of these two approaches. Fang [7] argued that in higher temperatures and humidity, the respiratory cooling system is insufficient, so the air can be perceived as stuffy and uncomfortable. The linear correlation between air acceptability and enthalpy observed by Fang indicates that respiratory cooling is necessary for an acceptable perception of air quality. Also, Toftum [8] studied the thermal perception of comfort felt due to the human respiratory cooling system on a group of panellists in order to test air quality. His experiment led to almost the same conclusions. The correlation between air freshness and humidity was also found by Berglund and Cain [9]. When the respiratory cooling effect drops to a certain level (humidity and temperature, in practice enthalpy), the air will be perceived as bad, regardless of whether it is clean or contaminated. What is interesting is that Berglund even considered the possibility of supplying cool and dry air to alleviate the perception of poor air quality, without removing contaminants. Fang's team [7] found a correlation between the acceptance of air pollution by panel members and enthalpy, which represents the energy content of air humidity. In the five tested levels of selected pollutants in the air (temperature ranges: 18,23 and $28^{\circ} \mathrm{C}$, and relative humidity (RH) ranges: $30 \%, 50 \%$ and $70 \%$ ), there were highly significant linear regressions of acceptability against the enthalpy of the evaluated air at five levels of pollution. At low enthalpy (low temperature and humidity), the level of contamination was a key factor in the perception of air quality, and air pollution was less important for the perceived air quality as air enthalpy increased. In addition to some enthalpy level, for example at $28{ }^{\circ} \mathrm{C}$ and relative humidity $70 \%$, temperature and humidity synergy were found to be the key determinants of perceived air quality. In this case, air was perceived as unacceptable, regardless of whether it was clean or not. In our article, we are interested in humid air without pollutants. A simple linear model was presented based on the results of Fang. The linear model of indoor air acceptability as a function of enthalpy using the following Equation (1) is:

$$
\mathrm{ACC}=\mathrm{a} \cdot \mathrm{h}+\mathrm{b}
$$

where, ACC is indoor air acceptability (takes values from sensory test -1 to 1 , where -1 is completely unacceptable, 1 is fully acceptable), $\mathrm{h}$ is air enthalpy $(\mathrm{kJ} / \mathrm{kg})$, and a and $\mathrm{b}$ are linear regression coefficients different for specific air pollution levels. For clean air, the relationship was found to be as follows (2):

$$
\mathrm{ACC}=-0.033 \cdot \mathrm{h}+1662
$$


Air acceptability (2) can be transformed using the Wargocki transformation into the percentage dissatisfied PD_Fang in \% using the formula provided in Reference [10] (3):

$$
P D_{- \text {Fang }}=\frac{100}{1+\frac{1}{\exp (-4.28 \cdot \mathrm{ACC}+0.42)}}
$$

According to authors, analysing a building's comfort using a percentage of dissatisfied PD offers many benefits. Various elements of the assessed indoor comfort can be integrated and the indicator is easily understood with the model IEQ developed by our team in Building Research Institute (ITB) [11], with the logistic regression IEQ model verified in Hong Kong [12] and with a literature review of the IEQ models creation [13]. The $P D$ indicator can be used to designate indoor environmental quality index (IEQ) and for a building's certification [14].

Toftum's team $[15,16]$ investigated the effect of humidity and temperature of inhaled air on perceived air acceptability. The air inhaled by subjects was rated as warmer and less acceptable with increasing air humidity and temperature. They developed a model that predicts the percentage of people dissatisfied with insufficient respiratory cooling depending on the actual evaporative and convective cooling of the airways (see Equation (4)). Both the temperature and humidity of the inhaled air had an impact on human perception of thermal breath sensitivity, freshness and acceptability. Respondents perceived inhaled air as cooler and more acceptable at lower temperatures and humidity. The results of this study confirmed the hypothesis that the perception of excess humidity is associated with the respiratory cooling system. Toftum's work resulted in a model for predicting the percentage of dissatisfaction with reduced respiratory cooling. The model is based on assessments of air at temperatures $\left(\mathrm{t}_{\mathrm{a}}\right)$ in the range of 20 to $29^{\circ} \mathrm{C}$ and vapour pressure $\left(\mathrm{p}_{\mathrm{a}}\right)$ in the range of $1000 \mathrm{~Pa}$ to $3000 \mathrm{~Pa}$. Enthalpy was in the range of 50 to $80 \mathrm{~kJ} / \mathrm{kg}$. The results, in accordance to Equation (4), indicate a rapid increase in dissatisfaction level with an increase in enthalpy above the $55 \mathrm{~kJ} / \mathrm{kg}$ value:

$$
\mathrm{PD}_{-} \text {Toftum }=\frac{100}{1+\exp \left[-3.58+0.18 \cdot\left(30-t_{a}\right)+0.14 \cdot\left(42.5-0.01 \cdot p_{a}\right)\right]}
$$

Another direction of using enthalpy for indoor comfort tests has been determined partly by the researchers dealing with the classic perception of thermal comfort. Thermal comfort is a condition in which a person feels that their body is in a state of natural heat balance, i.e., it feels neither warmth nor cold. The main research on thermal comfort was conducted by Fanger $[17,18]$. The results of his research became the basis for the development of the international standard (ISO) 7730 standard [19] on the analytical determination and interpretation of thermal comfort using the calculation of PMV and PD indicators and criteria of local thermal comfort and any other interesting articles validating the model, e.g., Reference [6]. PD is an indicator related to thermal comfort in indoor environments [20], finding use in the engineering assessment of the thermal comfort of rooms, this is the expected percentage of dissatisfaction with the thermal conditions in the room. People who choose $-3,-2,+2,+3$ on the predicted mean vote scale (PMV) during the experiment are considered dissatisfied with the thermal comfort in the room. PMV for nearly zero energy buildings is converted into $P D$ in \% according to the author's empirical formula [6] from the experiment validating the Fanger model:

$$
P D=100-99.9 \cdot \exp \left(-0.0355 \cdot \mathrm{PMV}^{4}-0.242 \cdot \mathrm{PMV}^{2}\right)
$$

The PMV model is based on the identification of skin temperature and sweating rate required for optimal comfort conditions, based on experimental data and literature e.g., from Rohles and Nevins [21]. Thermal comfort has been characterised by taking into account the parameters of the environment and the human body, using models of extended heat transfer. Increased dissatisfaction according to model (4) is significantly higher than in classic models of thermal comfort based on Fanger's model (5). These 
indicate the considerable importance and potential of including this approach for planning nearly zero energy buildings assessments.

Further research on the Fanger model included the process of adapting people to thermal conditions. Van Hoof et al. [22] have reviewed thermal comfort models for indoor applications from the second half of the 1990s to 2010. Djongyang [23] reviewed the contribution of the adaptive model approach, addressing the behavioural and psychological adaptation of people in an indoor environment. Halawa and van Hoof [24] have reviewed the adaptive model approach. Croitoru [25] refers in more detail to human thermophysiological models and adaptive psychological models, again promoting the combination of the human body thermoregulation model with the numerical approach as the most effective tool for assessing thermal comfort in an indoor environment. Air humidity was addressed by ASHRAE, which developed a standard for building comfort requirements. The standard is known as ASHRAE Standard 55: 2017 [26]. The purpose of this standard is to define a combination of indoor thermal environmental and personal factors that create thermal environmental conditions, which are acceptable to most residents in the building space. One of the most recognisable features of the Standard 55 is the "ASHRAE Comfort Zone" presented on a modified psychrometric chart. The standard allows the use of thermal comfort charts in places where people have certain levels of activity that cause a metabolic rate in the range of 1.0 to 1.3 met $(\mathrm{kcal} / \mathrm{kg} / \mathrm{hour})$, and where clothes provide thermal insulation from 0.5 clo to $1.0 \mathrm{clo}\left(1 \mathrm{clo}=0.155 \mathrm{~m}^{2} \mathrm{~K} / \mathrm{W}\right)$. The comfort zone is based on PMV values from -0.5 to +0.5 . Enthalpy recognised by ASHRAE as comfortable is in the range of 35 to $55 \mathrm{~kJ} / \mathrm{kg}$ in winter and 40 to $60 \mathrm{~kJ} / \mathrm{kg}$ in summer.

The results on human perception to high humidity in higher temperatures, as provided in Reference [27], indicated that the impact of humidity on human responses was significant and increased with an increase in air temperature when the relative humidity was above $70 \%$. The indoor comfort in hot-humid conditions was also studied by Kleber and Wagner [28]. A total of 136 subjects were tested in a climate chamber with specific hot-humid conditions in a test facility at the Karlsruhe Institute of Technology. Nine experimental conditions with high operative temperature and different relative humidity levels $\left(26,28\right.$ and $30{ }^{\circ} \mathrm{C}$ combined with $50 \%, 65 \%$ and $80 \%$ humidity) were studied. The significant influence of air humidity on indoor air quality and thermal perception was found. The acceptability of indoor air quality under temperatures of 26 to $30^{\circ} \mathrm{C}$ and $\mathrm{RH}$ of $60 \%$ to $80 \%$ was also studied by $\mathrm{He}$ et al. from Hunan University [29]. The authors confirmed a significant increase in dissatisfaction level for higher humidity. In Reference [30], Jing et al. studied the influence of relative humidity on thermal comfort in an environmental chamber. Twenty subjects were exposed to nine combinations of humidity and temperatures. Once again, higher humidity had a negative effect on the subjects' thermal comfort. Zhai [31] examined the effects of air movement from ceiling fans on subjective thermal comfort and perceived air quality for hot-humid environments. In a climate chamber controlled at three temperatures $\left(26,28\right.$ and $30^{\circ} \mathrm{C}$ ) and two relative humidity levels ( $\mathrm{RH} 60 \%$ and $80 \%$ ), sixteen subjects dressed in summer clothing ( $0.5 \mathrm{clo}$ ) were exposed to seven levels of air speed ranging from $0.05 \mathrm{~m} / \mathrm{s}$ to $1.8 \mathrm{~m} / \mathrm{s}$. The subjects were asked to evaluate thermal sensation, comfort and perception of indoor air quality. Without air movement, the unacceptable limit established by the ASHRAE standard 55 was reached very quickly even with moderate humidity. In Reference [32], Buonocore studied naturally ventilated building environments to evaluate the influence of relative humidity and air speed on the occupants' thermal perception. Indoor environmental variables were measured alongside questionnaires, focusing on thermal environment and air movement evaluation. The results indicated that relative humidity had a significant negative impact on thermal perception. Rana [33] used subjective responses in surveys as grounds to validate the performance of the thermal comfort prediction. The results confirm that humidity index may be an important predictor of indoor comfort at high humidity. The impact of humidity on the comfort of building users is also analysed in the literature on human comfort [34].

The relationship between indoor air humidity and the humidity of the partitions and walls that are not discussed in this publication have been presented and discussed by Kaczorek [35] and 
Krause [36,37]. Air humidity also has a significant impact on the building's energy consumption, which was, for example, discussed by Gawin [38].

In the Discussion Section, the authors refer to studies focused on sensory comfort evaluation tests, and the results are compared.

\subsection{Research Hypothesis}

In Reference [39], research focused on tropical climates found that the International standard for indoor climate, ISO 7730 based on Fanger's predicted mean vote (PMV/PD) equations, does not adequately describe comfortable conditions in a wide spectrum of temperatures and humidity. This paper presents some of the evidence and suggests ways in which ISOs are failing in determining the implications of air humidity. The direct impact of air humidity on air quality has been studied in a relatively small number of papers. The perception of IEQ in hot humid conditions was studied in References [7,15] in ventilated ecological houses [40] and in a climate test facility [28], where for higher temperatures and humidity, the dissatisfaction of users with indoor air quality (respiratory cooling) is higher than the discomfort associated with the thermal sensation. Taking this into consideration, the authors' intention was to analyse the actual humidity impact on the perception of building occupants in an experimental study, taking place in a test chamber located in a low-energy building. The authors believe that air enthalpy is the most suitable indicator for determining the effects of humidity on user comfort (as a percentage of dissatisfaction with IAQ) at selected conditions. Related studies on the impact of humidity on air quality have usually been carried out using a method in which users inhaled air with specified pollutants, vapour gradients and varying temperatures (also without indoor pollutants) $[7,15]$. The authors of this article put forward the thesis that one should not conduct experimental tests of actual thermal comfort and air quality of the indoor environment separately because indoor air discomfort in hot and humid environments may be higher than thermal discomfort. Example results of the percentage of dissatisfied $P D$ estimated in the enthalpy function resulting from the Fanger model and the ISO 7730 standard based on general human thermal balance ( $P D_{\text {_ISO7730, }}$ Table 1) and results obtained in models based on thermal sensations resulting from respiratory cooling comfort models ( $P D_{-}$Fang, $P D_{-}$Toftum, Table 1$)[7,15]$ differ significantly (especially for higher enthalpies), as shown in Table 1 for selected temperatures, humidity and calculated enthalpy values (clothing level $=0.6$ clo, metabolic rate $=1.1$ met). Enthalpy $(\mathrm{h})$ and $P D$ for sample temperatures and humidity are obtained by the Monte Carlo simulation and related model implementation. Based on Table 1, it can be concluded that for rooms with increased air enthalpy, the Fanger thermal comfort model may not be suitable for the overall indoor human comfort assessment. Significant discomfort occurs due to the comfort associated with air quality. This research subject was analysed in this paper by the experimental approach.

Taking into consideration the differences of up to several dozen percent in the results of the expected percentage of indoor environment dissatisfaction (Table 1, air quality versus thermal comfort), the authors decided to conduct an experiment in order to empirically analyse the humidity impact on human comfort under comparable boundary conditions. In the indoor environment of the building, almost zero energy-specific conditions with increased humidity and temperature were identified, enabling the use of surveys to determine the percentage dissatisfied.

The authors hypothesise that it is possible to express the percentage of dissatisfaction in conditions of increased humidity and temperature as the function, probably logarithmic as the Weber-Fechner law, of the enthalpy stimulus. The hypothesis originates in the science of the physiology of the human body, for which the universal Weber-Fechner law should apply [41,42]:

$$
\mathrm{R}=\mathrm{k} \cdot \ln (\mathrm{S})
$$

where $\mathrm{R}$ is the human perceptual variable related to stimulus, $\mathrm{S}$ is the stimulus of the environment causing the response and $\mathrm{k}$ is the ratio of proportionality. The authors' intention is to check 
experimentally whether in an indoor hot and humid environment Equation (6) can be used where enthalpy is an important stimulus (Equation (7)):

$$
P D_{-} \exp =\mathrm{k} \cdot \ln \left(\frac{\mathrm{h}}{\mathrm{h}_{\mathrm{th}}}\right)
$$

where $P D_{\text {exp }}$ is the percentage of dissatisfaction with the enthalpy $(\%), \mathrm{h}$ is the actual enthalpy $(\mathrm{kJ} / \mathrm{kg})$ and $\mathrm{h}_{\mathrm{th}}$ is the border neutral enthalpy for user perception $(\mathrm{kJ} / \mathrm{kg})$.

Table 1. Percent dissatisfied $(P D)$ estimated for three human comfort models for selected indoor environment data (Monte Carlo method), where $P D_{-I S O 7730}$ values are estimated using the Fanger thermal comfort model, $P D \_$Toftum is estimated using the indoor air acceptance model (4) and PD_Fang is estimated using the indoor air acceptance model—Equations (2) and (3) (under the assumptions: air speed $<0.1 \mathrm{~m} / \mathrm{s}, 0.6$ clo, 1.1 met, $\mathrm{t}_{\mathrm{a}}=\mathrm{t}_{\mathrm{mr}}$ ).

\begin{tabular}{|c|c|c|c|c|c|}
\hline $\begin{array}{l}{ }_{\mathbf{t}_{\mathbf{a}}} \\
{ }^{\circ} \mathrm{C}\end{array}$ & $\underset{\%}{\mathrm{RH}}$ & $\begin{array}{c}\mathrm{h}^{1} \\
\mathrm{~kJ} / \mathrm{kg}^{2}\end{array}$ & $\underset{\%}{P D_{-I S O 7730}}$ & $P D_{\frac{\sigma_{0}}{\text { Toftum }}}$ & $\begin{array}{c}P D_{\text {_Fang }} \\
\%\end{array}$ \\
\hline 26 & 50 & 53 & 8 & 32 & 39 \\
\hline 27 & 50 & 56 & 15 & 40 & 50 \\
\hline 28 & 50 & 58 & 26 & 48 & 58 \\
\hline 26 & 60 & 58 & 9 & 43 & 58 \\
\hline 27 & 60 & 61 & 18 & 52 & 65 \\
\hline 28 & 60 & 65 & 30 & 61 & 69 \\
\hline 26 & 70 & 64 & 11 & 55 & 68 \\
\hline 27 & 70 & 67 & 21 & 64 & 73 \\
\hline 28 & 70 & 71 & 34 & 73 & 76 \\
\hline 26 & 80 & 70 & 13 & 66 & 75 \\
\hline 27 & 80 & 73 & 24 & 75 & 78 \\
\hline 28 & 80 & 77 & 39 & 82 & 80 \\
\hline 26 & 90 & 75 & 15 & 76 & 79 \\
\hline 27 & 90 & 79 & 27 & 83 & 81 \\
\hline 28 & 90 & 83 & 44 & 88 & 83 \\
\hline 29 & 90 & 88 & 62 & 92 & 85 \\
\hline
\end{tabular}

${ }^{1}$ For enthalpy calculation, the Magnus-Tetens and Clausius-Clapeyron approximation was used as the accepted method in climatology.

Hypothetically, it is assumed that the enthalpy neutral for users $\left(h_{t h}\right)$ is in the range of 50 to $55 \mathrm{~kJ} / \mathrm{kg}$, which has to be confirmed by tests. The authors hypothesise that the Fanger model applies only to the threshold/neutral enthalpy value, and that the above models similar to Fang and Toftum are valid for a general comfort assessment. Also, Jokl [43] conducted research on the introduction of the Weber-Fechner law to assess thermal comfort but he did not confirm the relationship experimentally.

\section{Materials and Methods}

The main research objective is to express the percentage of user dissatisfaction in conditions of increased humidity and temperature in indoor building environment as the function of air enthalpy, $P D=f(h)$, by experimental evaluation. Based on the hypothesis, the authors set out to empirically determine the role of enthalpy in indoor comfort models by sensory evaluation tests undertaken in the NZEB building.

\subsection{Research Scheme and Approach}

For illustrative purposes, the authors provide a research scheme in Figure 1. 


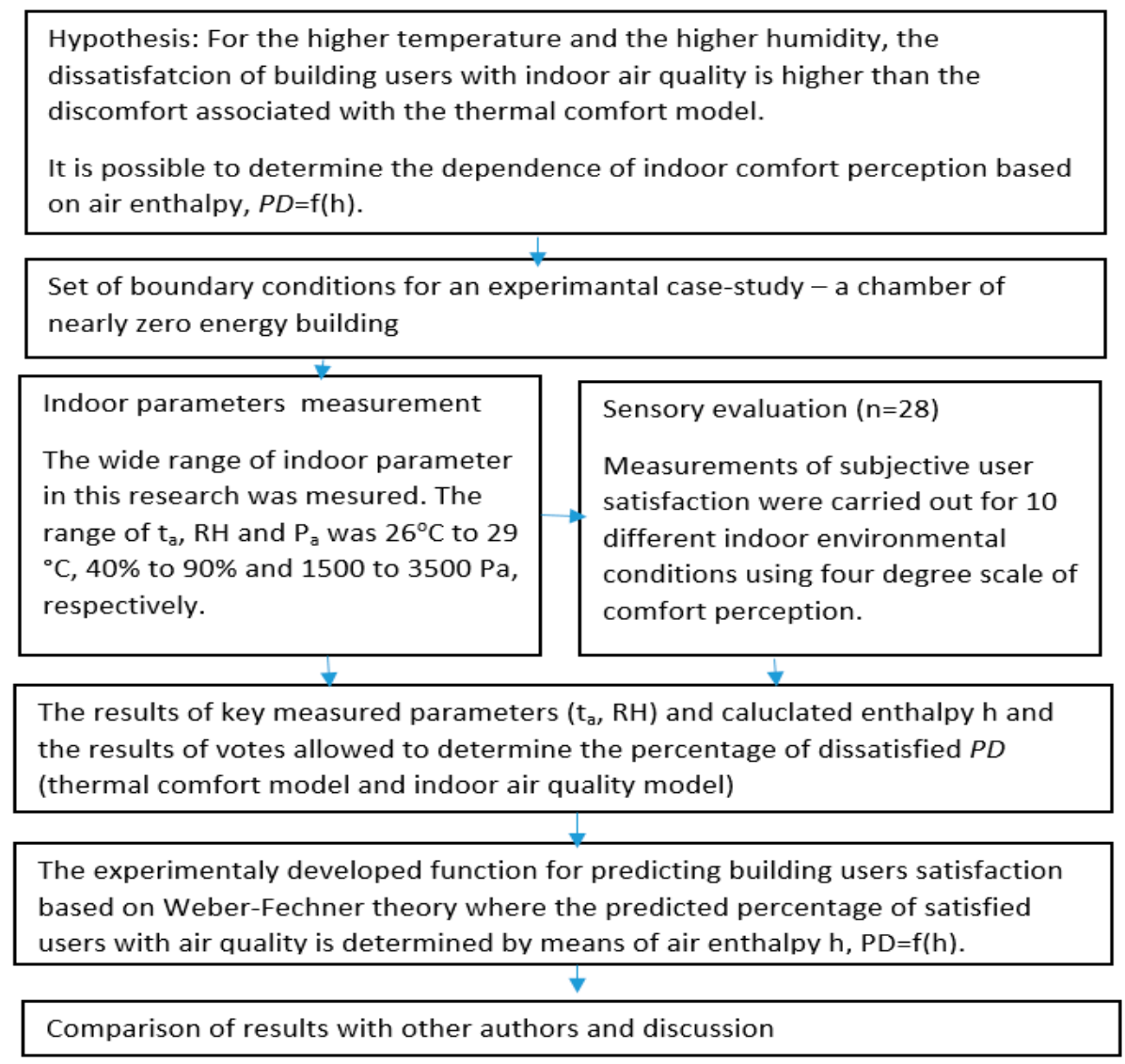

Figure 1. The assumptions and steps of the experiment.

\subsection{Experimental Facilities}

The test on users' perception of indoor air quality in hot and humid environments at NZEB office buildings was carried out in the experimental chamber of a nearly zero energy building (Central Europe), designed for physics tests in "in situ" conditions. Figure 2 shows a test functionality of the test chamber. The test room is thermally and acoustically insulated from the rest of the building. It is mainly warmed by heated walls and floors, and by a fan coil unit, which may additionally heat air if necessary. Building Management System (BMS) allows to control the room and wall temperatures, humidity, the number of exchanges and the concentration of $\mathrm{CO}_{2}$ in the air. Additional humidity generating devices (M1-M3) were located in the room to help maintain a high level of humidity $(\mathrm{RH}>$ $70 \%$ ). A total of 14 subjects could be in the room at each test.

The main measurement system (MC point at Figure 2) of the indoor environment was set up in front of the panel group. In addition, several testing sets were used by the authors to determine the homogeneity of thermal conditions in the room. The ventilation rate was about one air exchange per hour. The respondents answered questions (votes) in artificial light: $450 \pm 50$ lux. The measured $\mathrm{CO}_{2}$ concentration level (for tests) did not exceed $1000 \pm 30 \mathrm{ppm}$. The measured Total Volatile Organic Compounds (TVOC) air concentration levels did not exceed $150 \pm 36 \mu \mathrm{g} / \mathrm{m}^{3}$. Throughout the test, the authors took the necessary measures and actions to remove the potential asymmetry of the temperature field, air flow and humidity in the chamber, "quasi-stabilising" the indoor conditions before each test and maintaining the continuity of conditions during the test. The air speed was set at $0.1 \pm 0.05 \mathrm{~m} / \mathrm{s}$. The difference between radiant temperature and air temperature was controlled "online" by a building management system (BMS) as less than $\pm 1^{\circ} \mathrm{C}$. The measured vertical air temperature gradient was less than $\pm 1^{\circ} \mathrm{C}$ between the floor and the head of a seated person. The temperatures in the laboratory room changed by no more than $\pm 1{ }^{\circ} \mathrm{C}$ at each test point. This was ensured by the heating of the walls and floor in the test room. 


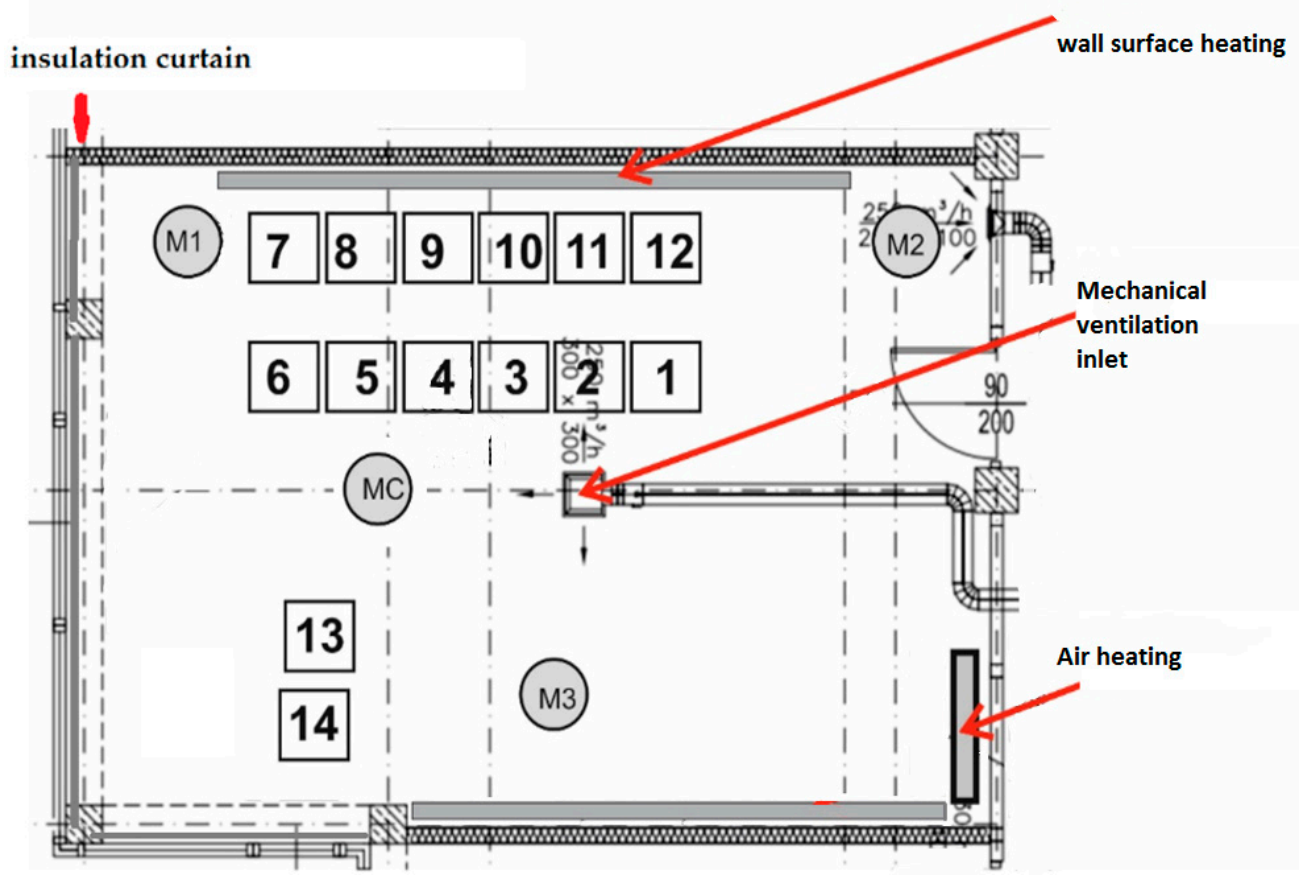

Figure 2. Chamber for measuring indoor comfort (where 1-14 are seats for participants in the sensory tests, M1-M3 are devices for generating high humidity, and MC is the location of microclimate sensors).

Outdoor conditions were monitored throughout the experiment, but the authors made an assumption that the variability of atmospheric conditions does not influence the specific results of the experiment in a statistically significant way and a test chamber of NZEB is sufficiently well insulated from the outdoor environment.

\subsection{Enthalpy Determination Method}

The enthalpy value, $\mathrm{h}$, in $\mathrm{kJ} / \mathrm{kg}$ was determined for all temperature and humidity conditions (ten tests). Enthalpy, $h$, was calculated on the basis of measured air temperature $\left(t_{a}\right)$ and humidity $(R H)$ using the ideal gas law, as follows:

$$
\mathrm{h}=\mathrm{h}_{\mathrm{a}}+\mathrm{w} \cdot \mathrm{h}_{\mathrm{g}}
$$

where:

$h_{a}=1.006 \cdot t_{a}$, dry air enthalpy,

$h_{\mathrm{g}}=$ water vapour enthalpy,

$t_{a}=$ measured air temperature,

$\mathrm{w}=0.622 \cdot \mathrm{P}_{\mathrm{a}} /\left(\mathrm{P}_{0}-\mathrm{P}_{\mathrm{a}}\right)$, humidity factor,

$\mathrm{w} \cdot \mathrm{h}_{\mathrm{g}}=\mathrm{w} \cdot\left(2501+1.805 \cdot \mathrm{t}_{\mathrm{a}}\right)$, water vapour enthalpy multiplied by the humidity factor,

$\mathrm{P}_{\mathrm{a}}=\mathrm{RH} / 100 \cdot \mathrm{P}_{\mathrm{S}}$, partial pressure of water vapour,

$\mathrm{P}_{\mathrm{s}}=610.94 \cdot \exp \left(17.625 \cdot \mathrm{t}_{\mathrm{a}} /\left(\mathrm{t}_{\mathrm{a}}+243.04\right)\right)$, saturation vapour pressure $(\mathrm{Pa})$, and

$\mathrm{P}_{0}=$ atmospheric pressure.

In the designed test condition, the calculated enthalpy values were in the range of 50 to $90 \mathrm{~kJ} / \mathrm{kg}$.

\subsection{Thermal Comfort Model-Measurements}

The level of thermal discomfort was also determined in the experiment using a measuring device. PMV and PD were calculated in accordance to ISO 7730 for each sensory test. PMV/PD are reference 
parameters for thermal environmental assessment, as provided in standard EN 16798-1 [44]. PMV is a function of measured physical parameters as presented:

$$
P M V=f\left(t_{a}, t_{m r}, v_{a}, p_{v} M, I_{c l}\right)
$$

where $t_{a}$ is the measured indoor air temperature $\left({ }^{\circ} \mathrm{C}\right), t_{m r}$ is the radiant temperature $\left({ }^{\circ} \mathrm{C}\right), v_{a}$ is the measured air velocity $(\mathrm{m} / \mathrm{s}), p_{v}$ is the water vapour partial pressure $(\mathrm{Pa}), \mathrm{M}$ is the human metabolic rate $\left(\mathrm{W} / \mathrm{m}^{2}\right)$ and $I_{c l}$ is the human clothing insulation $\left(\mathrm{m}^{2} \mathrm{~K} / \mathrm{W}\right)$. All these parameters were measured and determined. The clothing level of was calculated at $0.6 \mathrm{clo}$, and metabolic rate was set at 1.1 met. The measurement methodology was based on ISO 7726. In practice, the values of PMV and PD_ISO7730 were obtained by measurement equipment but for validation purposes, they were re-calculated using the web tool found at http://comfort.cbe.berkeley.edu/EN of the Centre for the Built Environment, University of California, Berkeley. The obtained PD_ISO7730 results using the normative ISO method formed the basis for comparing the thermal comfort model with experimental results obtained from the assessment of indoor air quality perception.

\subsection{Air Perception Sensory Evaluation Tests-Vote}

The survey evaluation involved 28 subjects, students of the University of Technology, in two sessions (day 1 and day 2) on 7 November and 9 December 2019. The panellists group was ethnically homogeneous, with variation $100 \%$ white Caucasian. $20 \%$ were men and $80 \%$ women; however, gender differences were not included in the results discussion. The authors assume that the perception of comfort depends on body parameters and not on gender directly. The participants signed their consent to participate in the tests and declared their health state and anthropometric parameters prior to the tests. The anthropometric data characterising the panel group is provided in Table 2.

Table 2. Anthropometric data of tested panel groups with expanded uncertainty at the confidence level of $1-\alpha=0.95$.

\begin{tabular}{ccccccccc}
\hline Group & Gender & $\begin{array}{c}\text { Group } \\
\text { Size }\end{array}$ & $\begin{array}{c}\text { Age } \\
\text { (years) }\end{array}$ & $\begin{array}{c}\text { Height } \\
(\mathbf{c m})\end{array}$ & $\begin{array}{c}\text { Body Weight } \\
(\mathbf{k g})\end{array}$ & $\begin{array}{c}\text { Skin Surface } \\
\text { “DuBois" (m²) }\end{array}$ & $\begin{array}{c}\text { Body Mass } \\
\text { Index }\end{array}$ & $\begin{array}{c}\text { Clothing } \\
\text { Insulation (clo) }\end{array}$ \\
\hline $\begin{array}{c}\text { Academic } \\
\text { youth }\end{array}$ & Mean & 28 & $23 \pm 1$ & $167 \pm 8$ & $62 \pm 10$ & $1.8 \pm 0.3$ & $22 \pm 4$ & $0.6 \pm 0.1$ \\
\hline
\end{tabular}

The panellists group had a BMI of $22 \pm 4$. The neutral limit of body weight is in the range of 18.5 $<$ BMI $<24.9$. The value of clothing's thermal resistance (clo) between women and men was averaged and calculated. The fact that some women have long hair and wear extra underwear (like bras) was included in the uncertainty estimation. Subjects were wearing long trousers, short-sleeved shirts and shoes, which provides an insulation of clothes $\left(\mathrm{I}_{\mathrm{clo}}\right)$ at $0.6 \pm 0.1 \mathrm{clo}$. The performed physical activity was set as $1.1 \pm 0.15$ met (semi-active sitting/working in a seated position). The group remained air-conditioned in neutral conditions ( $N$, Figure 3 ) before each test at PMV $=-0.1 ; t_{a}=23{ }^{\circ} \mathrm{C}, \mathrm{RH}=$ $40 \%$. The respondents evaluated their comfort perception in writing using the air acceptance vote considering temperature and humidity. The provided question was: determine using a 4-degree scale whether prevailing air conditions including actual humidity and temperature are comfortable for work, where $0=$ neutral (comfortable), 1 = just comfortable, 2 = just not comfortable, $3=$ not comfortable. Participants knew that air quality would be tested for different temperatures and humidity, but no values were given for actual parameters. Voting took place after about 15 minutes of being in the tested conditions in accordance to the experimental timetables (Figures 3 and 4). After each vote, the subjects returned to thermally neutral conditions (second room). Due to the number of voting places in the test room (maximum of 14), the panel group was divided into two smaller A and B groups voting at 15-minute intervals under the same temperature conditions. On day 1 , in group $\mathrm{A}$, there were 12 panellists, while in group B there were 11. On day 2, there were 14 panellists in groups A and B ( $\mathrm{n}=$ 
28). Figures 3 and 4 present the timetable of experiments. At day 1, six panellists were excluded from the experiment for being too late, having cold symptoms or wearing unsuitable clothing.

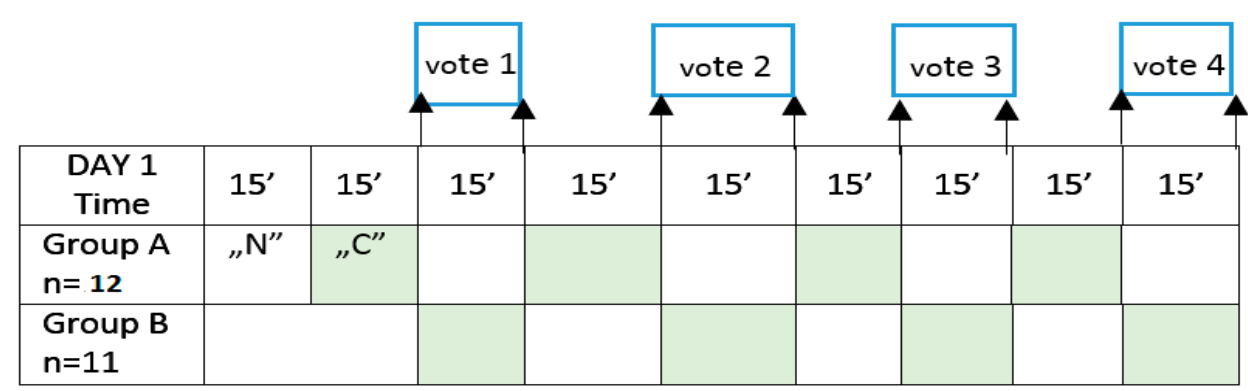

Figure 3. Experimental timetable (day 1, $\mathrm{n}=23$, “ $\mathrm{N}$ ”- neutral conditions, “ $\mathrm{C}$ "—-test chamber).

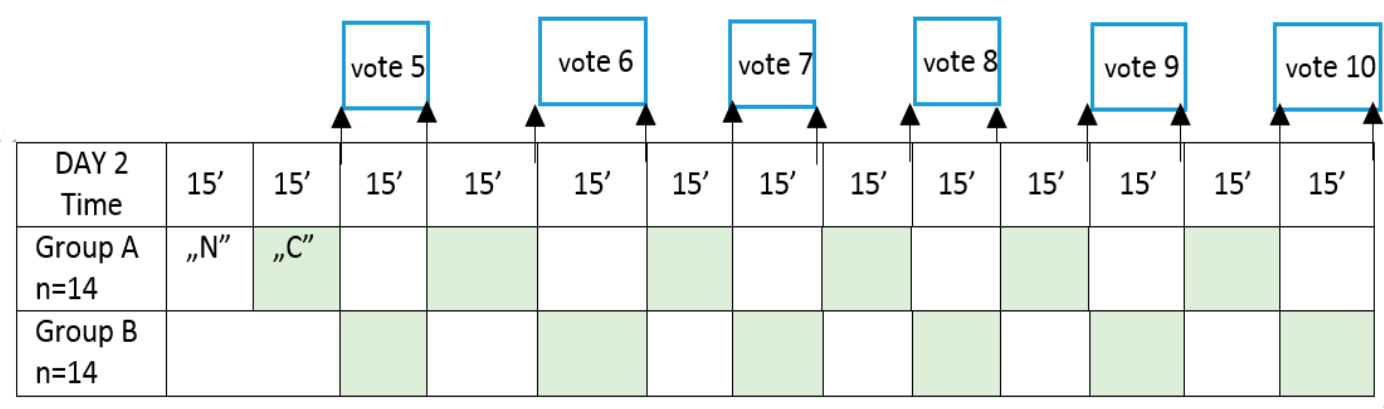

Figure 4. Experimental timetable (day 2, $\mathrm{n}=28$, , $\mathrm{N}$ ”-neutral conditions, “ $\mathrm{C}$ "—-test chamber).

The experiment was conducted for ten specific conditions with different values of air enthalpy. While conducting the experiment, the authors took into account the level of energy required for metabolism, i.e., the demand for food (decided on a 3-hour maximum). The group did not consume meals for up to two hours before the study and during the tests. During the test, students were allowed to drink water (0.5 1 maximum) to supplement their needs related to the secretion of sweat. A longer experiment could cause disturbances in the concentration of young people, and the aim was to maintain activity on the same level for 2 to 3 hours.

The authors did not take into consideration other human factors that may affect the results of comfort tests including: psycho-conditions, physiological circadian (day) rhythm and the level of nutrition before tests. Aware of the limitations, the authors argued that these conditions had a statistically minor significant impact on the results obtained, well within the calculated expanded uncertainty of $26 \%$.

\subsection{The Measuring Equipment}

The range of indoor parameters was 26 to $29{ }^{\circ} \mathrm{C}$, humidity was $40 \%$ to $90 \%$ and vapour pressure was 1500 to $3500 \mathrm{~Pa}$. In such conditions, the enthalpy values were in the range of 45 to $90 \mathrm{~kJ} / \mathrm{kg}$. The indoor air parameters measurement device (MC) was located in the middle of the test area. Figure 5 shows the device used for measuring thermal indoor parameters: $t_{a}=$ actual air temperature, $t_{g}=$ temperature of black globe probe (heat radiation meter), $\mathrm{t}_{\mathrm{nw}}=$ wet-bulb temperature, $\mathrm{RH}=$ relative air humidity and $\mathrm{v}_{\mathrm{a}}=$ air flow speed. The measurements of physical indoor parameters were provided at three height levels: $0.05,1$ and $1.6 \mathrm{~m}$ above floor level in parallel. Only the chest level (1 m) of seated participants was considered for further calculations. 


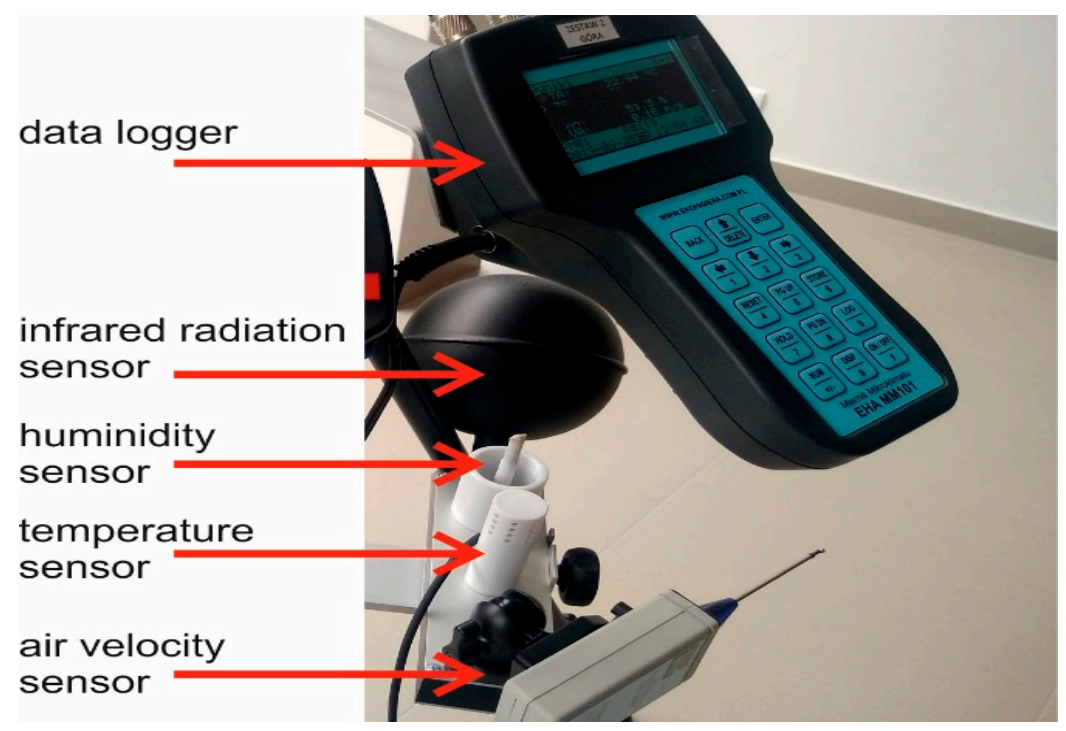

Figure 5. Sensors of the EHA-MM101 device for indoor environment tests (MC).

Measurements at three heights allowed for the reduction of any possible negative gradient of vertical temperature. The technical data and sensor resolution are presented in Table 3. All measuring sensors were calibrated by an accredited certifying laboratory.

Table 3. Sensors information.

\begin{tabular}{cccc}
\hline Sensor & Measurement Range & Resolution & Accuracy \\
\hline Temperature & -20 to $50{ }^{\circ} \mathrm{C}$ & $0.01{ }^{\circ} \mathrm{C}$ & $0.5^{\circ} \mathrm{C}$ \\
Humidity & $0 \%$ to $100 \%$ & $0.1 \% \mathrm{RH}$ & $5 \%$ \\
Air speed & 0.01 to $10 \mathrm{~m} / \mathrm{s}$ & $0.01 \mathrm{~m} / \mathrm{s}$ & $2 \%$ \\
Radiant temperature & 0 to $50^{\circ} \mathrm{C}$ & $0.01{ }^{\circ} \mathrm{C}$ & $2 \%$ \\
Carbon dioxide & 0 to $5000 \mathrm{ppm}$ & $0.1 \mathrm{ppm}$ & $1 \mathrm{ppm}$ \\
\hline
\end{tabular}

Other assumptions of the assessment methodology for determining thermal comfort were based on EN ISO 7730 [19]. The authors' intention was to maintain indoor air conditions in which the main pollutants are on a neutral level for the perception of users, as enthalpy is the only variable studied. Continuous $\mathrm{CO}_{2}$ measurement was carried out during the experiment by a FYAD00 sensor and other side devices integrated with the building management system (BMS). The mean carbon dioxide concentration during tests was $650 \pm 15 \mathrm{ppm}$, which corresponds to a neutral percentage of dissatisfaction $\left(P D_{\mathrm{CO} 2}<10 \%\right)$ in accordance to Reference [45] and [46]. During day 1 and day 2, a measurement of volatile organic compounds (VOCs) air pollution was carried out. The air was collected on Tenax adsorbent samples and transported to the laboratory, then tested using the ISO 16000-6 and ISO 16000-3 provisions. Air samples were thermally desorbed and analysed in a Shimadzu QP2010 chromatograph. The VOCs were identified by the mass spectral database. The mean of total VOCs concentration (TVOC) was $120 \mu \mathrm{g} / \mathrm{m}^{3} \pm 18 \%$, which corresponds to a neutral percentage of dissatisfaction $\left(P D_{T V O C}<5 \%\right)$ in accordance to Reference [47].

As part of the calculations, the realistic uncertainty of measurement for all measuring devices was determined Table 4. The standard deviation of panel 'votes' was 12.9\%. Uncertainties have been determined using the recommendations: for a model IEQ reliability analysis provided in Reference [48], for thermal comfort subjective test vote uncertainty analysis $[49,50]$. The specified expanded uncertainty of $P D \_$exp assessment for the provided experiment was $26 \%$. The uncertainty for enthalpy calculation considers the provisions in Reference [51]. The calculated effect of humidity on the enthalpy value in our research range had a standard deviation of $2.38 \%$, and the effect of temperature on the enthalpy 
value determination had a standard deviation of $0.96 \%$. The actual standard deviation of indoor air enthalpy determination in our case was $2.70 \%$.

Table 4. Overall uncertainty $(\mathrm{U})$ of experimental indoor perception evaluation (PD_exp $=\mathrm{f}(\mathrm{h})$ ) based on enthalpy determination uncertainties $\left(\mathrm{SD}_{\mathrm{h}}\right)$ and vote results $\left(\mathrm{SD}_{\text {vote }}\right)$.

\begin{tabular}{cccc}
\hline Parameter & $\begin{array}{c}\mathrm{SD}_{\mathbf{h}} \\
\%\end{array}$ & $\begin{array}{c}\mathrm{SD}_{\text {vote }} \\
\%\end{array}$ & $\begin{array}{c}\mathbf{U} \\
\%\end{array}$ \\
\hline PD_exp & 2.7 & 12.9 & $2 \cdot(7.29+166.4)^{-2}=26.4$ \\
\hline
\end{tabular}

The standard deviations of the estimated thermal insulation of clothes were $0.6 \pm 0.1 \mathrm{clo}$, and the metabolic rate of workers was $1.1 \pm 0.15$ met. The calculated uncertainty for the $P D_{I S O 7730}$ determination for Fanger thermal comfort was 3.22\%, considering References [48,52].

\subsection{The Boarder Assumptions}

The results refer to the buildings with a mechanical ventilation. The experiment results refer to the range of indoor parameters: temperature 26 to $29{ }^{\circ} \mathrm{C}$, relative humidity range $40 \%$ to $90 \%$ and the enthalpy range of 45 to $90 \mathrm{~kJ} / \mathrm{kg}$. The following assumptions were used for all tests: air speed $<0.1 \mathrm{~m} / \mathrm{s}, 0.6 \mathrm{clo}, 1.1 \mathrm{met}, \mathrm{t}_{\mathrm{a}}=\mathrm{t}_{\mathrm{mr}}$. These assumptions are valid for the experiment as well as all thermal comfort calculations.

The panellists group was ethnically homogeneous, Caucasian. Results may not be representative for other ethnic groups. $20 \%$ were men and $80 \%$ women; however, gender differences were not included in the results discussion. Due to the fact that the research was conducted on students, the results may not be representative for older people.

The authors assume that other potential air pollution factors than $\mathrm{CO}_{2}$ and TVOC (determined during the experiment) did not affect the subjects' satisfaction results obtained.

The subject group size $(n=28)$ affects the significance of the data analysis. In practice, the authors considered the sample size issue with Raosoft calculator (http://www.raosoft.com/samplesize.html) to set a minimum number of subjects. The authors adopted the following assumptions: the expected margin of error, the amount of error that we were able to tolerate, in our experience in sensory evaluations with panellists (students) is $20 \%$. The confidence level was $95 \%$. The global population size of university students was 14,000 . The minimum recommended size of our survey calculated was 24 . The authors set $n=28$ test subjects for practical and technical reasons. With the expanded uncertainty of $26 \%$, a sample of $28(\mathrm{k}=95 \%)$ ensures reproducibility and representativeness of the study.

\section{Results}

\subsection{Experimental Relation of Dissatisfaction with Perception of Indoor Air Condition}

The respondents evaluated their comfort perception in writing using the air acceptance vote (considering temperature and humidity). As part of the experiment, measurements of user satisfaction were carried out for ten different indoor environment conditions using a 4-degree scale (where " 0 " is neutral air conditions (comfortable), " 1 " is just comfortable, " 2 " is just not comfortable, and " 3 " is not comfortable). The results of key measured parameters $\left(t_{a}, R H\right)$ and calculated enthalpy (h), and the results of votes are presented in Table 5. Similar to other studies, like Fanger's, the number of dissatisfied participants was counted, including those who answered " 2 " or " 3 " in the survey. 
Table 5. Vote results-number of panellist votes using a 4-degree scale (whether prevailing air conditions are comfortable for work, where 0 is neutral (comfortable), 1 is just comfortable, 2 is just not comfortable, 3 is not comfortable) for 10 selected indoor conditions and the calculated percentage of dissatisfied (PD_exp).

\begin{tabular}{|c|c|c|c|c|c|c|c|c|c|}
\hline $\begin{array}{c}\text { Test } \\
\text { Number }\end{array}$ & $\begin{array}{l}\text { Number } \\
\text { of Votes }\end{array}$ & $t_{a}$ & RH & h & Numb & $\begin{array}{l}\text { Panel } \\
\text { omfo }\end{array}$ & $\begin{array}{l}\text { Votin } \\
\text { le "0" }\end{array}$ & egree & PD_exp \\
\hline- & - & ${ }^{\circ} \mathrm{C}$ & $\%$ & $\mathrm{~kJ} / \mathrm{kg}$ & “0” & "1" & "2" & “3" & $\%$ \\
\hline 1 & 23 & 27.2 & 44.9 & 53 & 11 & 8 & 3 & 1 & 17 \\
\hline 2 & 23 & 27.0 & 45.8 & 53 & 12 & 7 & 3 & 1 & 17 \\
\hline 3 & 23 & 26.8 & 44.8 & 52 & 13 & 8 & 2 & 0 & 9 \\
\hline 4 & 23 & 26.6 & 43.4 & 52 & 17 & 3 & 1 & 0 & 5 \\
\hline 5 & 28 & 28.3 & 56.8 & 63 & 0 & 16 & 8 & 4 & 43 \\
\hline 6 & 28 & 28.6 & 59.7 & 64 & 2 & 14 & 8 & 4 & 43 \\
\hline 7 & 28 & 28.5 & 62.3 & 68 & 2 & 13 & 10 & 3 & 46 \\
\hline 8 & 28 & 28.3 & 71.8 & 73 & 2 & 10 & 8 & 8 & 57 \\
\hline 9 & 28 & 27.6 & 80.5 & 77 & 1 & 3 & 6 & 16 & 79 \\
\hline 10 & 28 & 27.4 & 86.0 & 79 & 1 & 2 & 10 & 15 & 89 \\
\hline
\end{tabular}

The authors present the obtained results in the form of a relation of dissatisfaction with the perception of indoor conditions, $P D_{-} \exp =\mathrm{f}(h)$. In order to evaluate the shape of the curve, logarithmic regression was used to determine the experimental equation, consistent with the hypothesis that the $P D$ results should correspond to Weber-Fechner's law, where indoor air enthalpy $(\mathrm{h})$ is a stimulus (Figure 6).

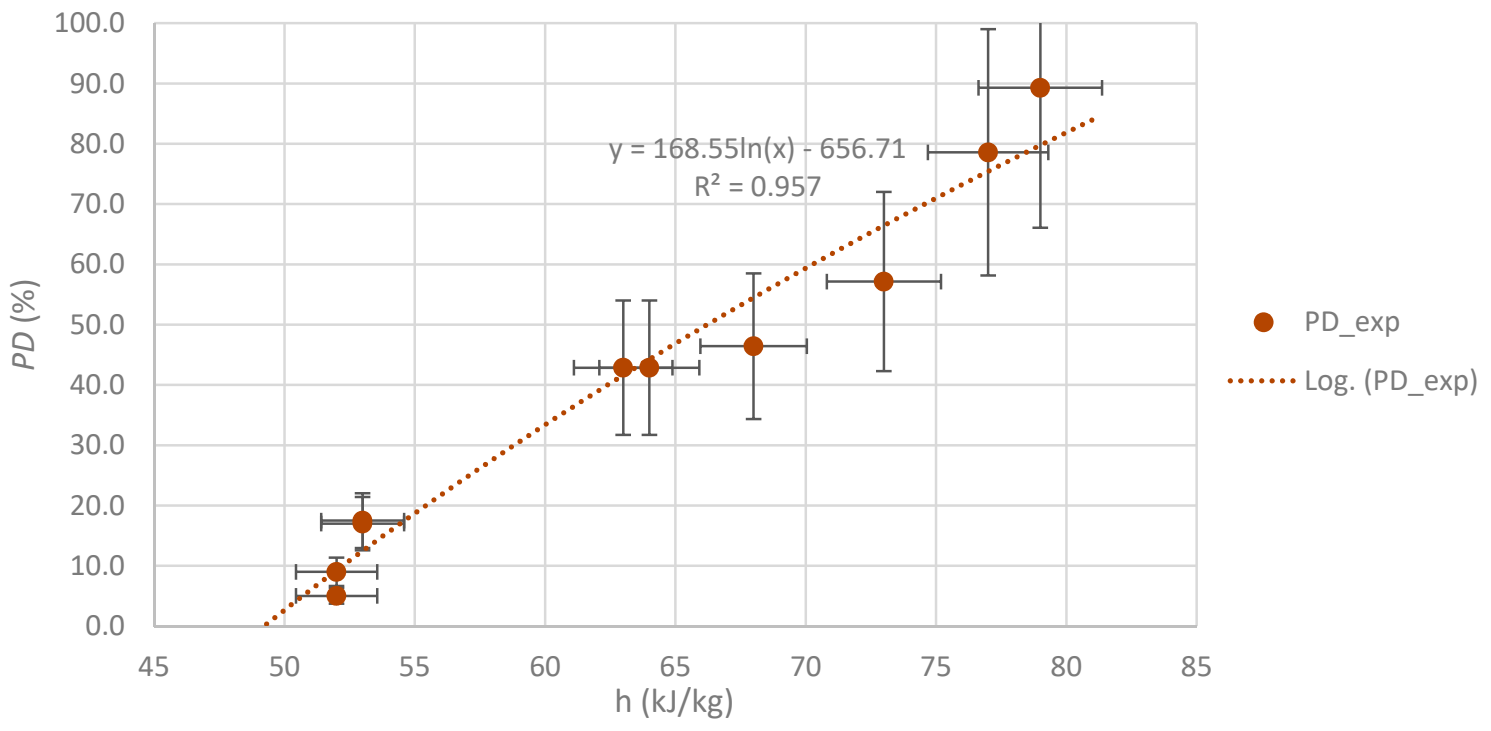

Figure 6. Percent of dissatisfied (subjects) in enthalpy function ( $P D_{\_}$exp), results of experimental research and regression line $\left(\ln .\left(P D \_\right.\right.$exp $\left.)\right)$under the following assumptions: air speed $<0.1 \mathrm{~m} / \mathrm{s}, 0.6$ clo, 1.1 met, $\mathrm{t}_{\mathrm{a}}=\mathrm{t}_{\mathrm{mr}}, \mathrm{c}_{\mathrm{CO} 2}<600 \mathrm{ppm}, \mathrm{c}_{\mathrm{TVOC}}<150 \mu \mathrm{g} / \mathrm{m}^{3}$.

There is an assumption that the human perception neutral enthalpy is a hypothetical point at percentage dissatisfied $(P D)=0 \%$. This enthalpy, $\mathrm{h}_{\text {th }}$, indicates a border neutral perception for an unpolluted hot and humid air quality, the border point of the TC comfort zone defined by the Fanger equation. From this point, the impact of higher enthalpy on users can be calculated from the converted regression equation. The converted experimental dependence of users' dissatisfaction $P D$ in $\%$ in the enthalpy function with $R^{2}=0.957$ takes the following form Equation (10):

$$
\text { PD_exp }=168.55 \cdot \ln \left(\frac{h}{49.22}\right)
$$


According to the results obtained, neutral enthalpy, $\mathrm{h}_{\mathrm{th}}$, is $49.2 \mathrm{~kJ} / \mathrm{kg}$. Fang obtains a corresponding value of neutral acceptance for $\mathrm{h}=45 \mathrm{~kJ} / \mathrm{kg}$, while Toftum obtains a value of $55 \mathrm{~kJ} / \mathrm{kg}$ [15]. In a thermal comfort assessment, a neutral value of enthalpy cannot be determined.

\subsection{Enthalpy Prediction for which the Thermal Comfort Model Gives Understated Results}

The method of enthalpy prediction for a given temperature, at which the results from the thermal comfort model are starting to be lower than the actual dissatisfaction (as shown by the experimental model), is provided. Figure 7 shows a comparison of the authors' experimental indoor air perception function (PD_exp) and the estimated results of the predicted percentage of satisfaction with the thermal comfort model for the same enthalpy range for the indoor conditions under the following assumptions: air speed $<0.1 \mathrm{~m} / \mathrm{s}, 0.6$ clo, 1.1 met, $\mathrm{t}_{\mathrm{a}}=\mathrm{t}_{\mathrm{mr}}$. PD_ISO values for thermal comfort were calculated using the Fanger model from ISO 7730. The thermal dissatisfaction results were estimated for three constant temperatures 26,27 and $28^{\circ} \mathrm{C}$. For a constant temperature value, $26^{\circ} \mathrm{C}$, and maximum relative humidity, $\mathrm{RH}=100 \%$, the maximum value of the dissatisfaction percentage is $17 \%$ (Figure 7 ). For a constant temperature value, $27^{\circ} \mathrm{C}$, and a maximum relative humidity, $\mathrm{RH}=100 \%$, the maximum value of the dissatisfaction percentage is $30 \%$ (Figure 7). For a constant temperature value, $28{ }^{\circ} \mathrm{C}$, and a maximum relative humidity, $\mathrm{RH}=100 \%$, the maximum value of the dissatisfaction percentage is $47 \%$. The comparison of the thermal comfort and indoor air quality models shows that $P D$ experimental values start to be higher from the intersection points $A$ to $C$ in Figure 7.

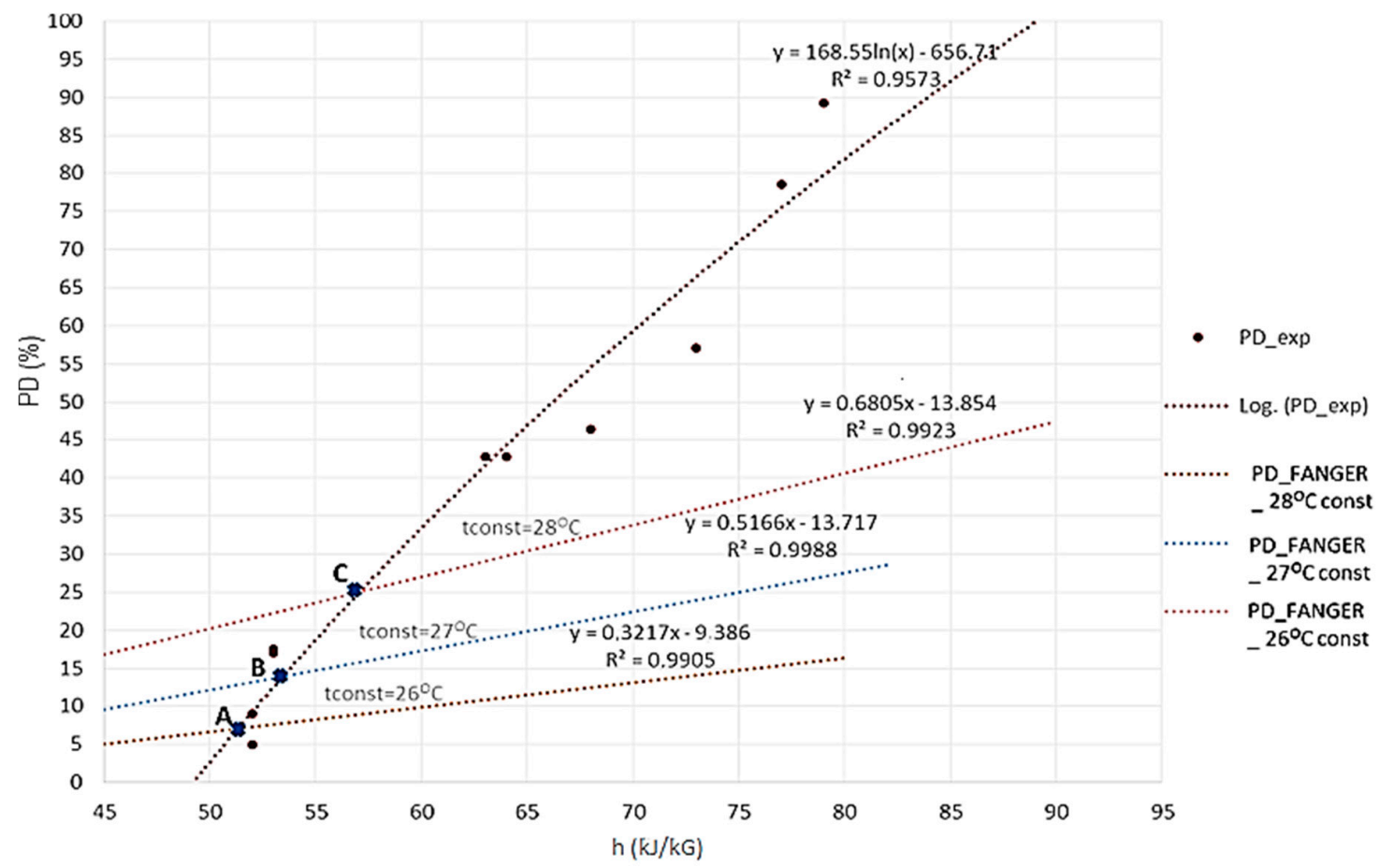

Figure 7. Comparison of the panel test results (black dots) of indoor air perception (PD_exp) with the results estimated using the thermal comfort model ( $\left.P D_{-I S O 7730}\right)$ for three constant temperatures: 26,27 and $28{ }^{\circ} \mathrm{C}$ (under the assumptions: air speed $<0.1 \mathrm{~m} / \mathrm{s}, 0.6 \mathrm{clo}, 1.1 \mathrm{Met}, \mathrm{t}_{\mathrm{a}}=\mathrm{t}_{\mathrm{mr}}$ ). Intersection points are presented in the graph with dots marked A, B and C. The PD_Fanger lines are interrupted in points where $\mathrm{RH}$ reaches $100 \%$.

The real (experimental) occupants' dissatisfaction level is higher than the PD level predicted with the help of the Fanger equation curves.

Enthalpy values $(h)$ for intersection points A, B and C are determined for three temperatures. The estimated humid air enthalpy points (at the three fixed temperatures) set the boundaries of the non-binding Fanger equation zone for human thermal comfort assessment. In practice, the intersection 
of logarithmic and linear functions can be solved by the numerical method. The mathematic solution involves the W Lambert Function [53]. Equation (11) takes the form:

$$
\mathrm{m}_{1} \cdot \mathrm{h}+\mathrm{c}_{1}=\mathrm{m}_{2} \cdot \ln (\mathrm{h})+\mathrm{c}_{2}
$$

where coefficients $\mathrm{m}_{1}$ and $\mathrm{c}_{1}$ describe the linear function of dissatisfied occupants based on Fanger's model, and $\mathrm{m}_{2}$ and $\mathrm{c}_{2}$ describe the experimental logarithmic relationship $P D=\mathrm{f}(h)$. A function (Equation (11)) can be rewritten as Lambert Function $x=W(x) \cdot e^{W(x)}$ in the form of Equation (12):

$$
-\frac{m_{1}}{m_{2}} e^{\frac{c_{1}-c_{2}}{m_{2}}}=-\frac{c_{1} \cdot h}{m_{2}} e^{\frac{-h \cdot c_{1}}{m_{2}}}
$$

which has the solution of Equation (13):

$$
h=-\frac{m_{2}}{m_{1}} \cdot W\left(-\frac{m_{1}}{m_{2}} \cdot e^{\frac{c_{1}-c_{2}}{m_{2}}}\right)
$$

For value $x$ calculated from the left side of Equation (12), value $\mathrm{W}(\mathrm{x})$ is read from Lambert's Function and used for $h$ in Equation (13). For instance (point B, Figure 7), if $m_{1}=0.5166, c_{1}=-9.386$ and $\mathrm{m}_{2}=168.55, \mathrm{c}_{2}=656.71, \mathrm{x}=-0.139$ gives $\mathrm{W}(\mathrm{x})=-0.164$, so (12) indicates $\mathrm{h}=53.4 \mathrm{~kJ} / \mathrm{kg}$. The enthalpy values obtained in accordance to Equations (11)-(13) are presented in Table 6. Equation (11) can be used to determine the enthalpy for a specific temperature at which the Fanger equation begins to indicate understated results to the actual dissatisfaction of users.

Table 6. The estimated humid air enthalpy points A, B and C calculated with Equation (13) (at three fixed temperatures, see Figure 7) set the boundaries of the non-binding Fanger equation zone for human thermal comfort assessment under the following assumptions: air speed $<0.1 \mathrm{~m} / \mathrm{s}, 0.6 \mathrm{clo}, 1.1 \mathrm{met}$ and $t_{\mathrm{a}}=\mathrm{t}_{\mathrm{mr}}$.

\begin{tabular}{ccccccc}
\hline Point & $\begin{array}{c}\mathbf{t}_{\mathbf{a}} \\
{ }^{\circ} \mathbf{C}\end{array}$ & $\begin{array}{c}\text { Parameter } \\
\mathbf{m}_{\mathbf{1}}\end{array}$ & $\begin{array}{c}\text { Parameter } \\
\mathbf{c}_{\mathbf{1}}\end{array}$ & $\begin{array}{c}\mathbf{x} \\
\mathbf{g}_{\mathbf{w}} / \mathbf{k g}_{\text {dryair }}\end{array}$ & $\begin{array}{c}\mathbf{h} \\
\mathbf{k J} / \mathbf{k g}\end{array}$ & $\begin{array}{c}\text { PD_exp } \\
\mathbf{\%}\end{array}$ \\
\hline $\mathrm{A}$ & 26 & 0.3217 & -9.386 & 9.9 & 51.3 & 7 \\
$\mathrm{~B}$ & 27 & 0.5166 & -13.717 & 10.2 & 53.4 & 14 \\
$\mathrm{C}$ & 28 & 0.6805 & -13.854 & 11.3 & 57.1 & 25 \\
\hline
\end{tabular}

\section{Discussion}

In the presented experiment, the authors confirmed that the impact of air humidity on user dissatisfaction related to indoor air quality has a greater impact on perception than a thermal sensation estimated based on the ISO 7730 model [19] and the ASHRAE Standard 55-2017 [26] for a hot and humid environment. Considering the significant increase in user dissatisfaction with indoor air quality for temperatures of 26 to $28{ }^{\circ} \mathrm{C}$ with enthalpy higher than $51.3,53.4$ and $57.1 \mathrm{~kJ} / \mathrm{kg}$, in relation to the $P D$ value resulting from the thermal comfort model, the authors state that due to the global user satisfaction and indoor environmental quality index, the thermal assessment model based on the ISO7730 standard should not be used, as it gives underestimated results. The authors state that the perception of thermal- and air-related comfort dominated on comfort thermal perception and cannot be separately perceived "in situ" by users. The authors recommend using the indoor air quality model instead of the thermal model for high enthalpies. The expected total percentage of dissatisfied users $(P D=100 \%)$ by experimental function is $\mathrm{h}=88 \mathrm{~kJ} / \mathrm{kg}$. Above this, there is a $95 \%$ probability that all users are dissatisfied. The presented isotherm based on the Fanger model indicates that the dissatisfaction percentage is two times lower than experimental $P D$ for $\mathrm{t}=28^{\circ} \mathrm{C}$ and three times lower for $27^{\circ} \mathrm{C}$. The experimental results find confirmation in some papers. In Reference [40], Simonson stated that humidity is exactly twice as important for IAQ than for thermal comfort. Investigation of indoor thermal comfort in hot and humid conditions in a German climate test facility was analysed 
by Kleber et al. [28]. The tests were conducted in a similar temperature and humidity range and the impact of humidity and temperature on the air quality perceived by subjects was taken into account. The results of Kleber, $P D_{-K l e b e r}$ (for $t_{\mathrm{a}} 26-28{ }^{\circ} \mathrm{C}$, RH 60\% to 80\%, subjects $\mathrm{n}=136$ ) and those published by Simonson, PD_Simonson (for $28{ }^{\circ} \mathrm{C}, \mathrm{RH} 60 \%-80 \%$ ) are compared with our experimental results (PD_exp) in Figure 8.

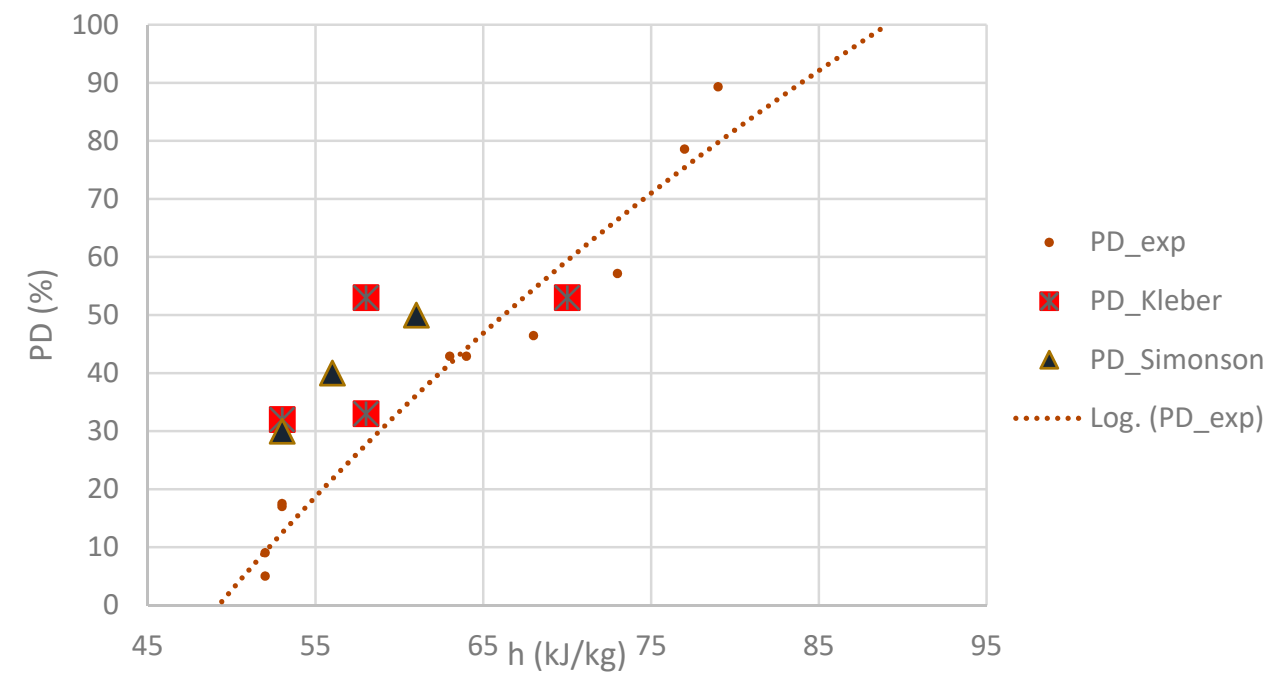

Figure 8. Comparison of the experimental results of indoor discomfort perception (log.PD_exp) with the former research presented by Kleber (PD_Kleber $)$ [28] and Simonson (PD_Simonson $)$ [40].

The results of Kleber show even higher dissatisfaction of air quality perception values for the same enthalpies. The results are correlated and follow the same trend. They indicate a higher level of dissatisfaction than the thermal comfort model in similar conditions. The key point of discussion is to compare the experimental results with the results obtained by Fang [7] and Toftum [15], who conducted studies on the impact of temperature and humidity on the IAQ perception of subjects $(n=$ 38 and 40). The results obtained by Toftum, presented in Figure 9 (PD_Toftum), were calculated based on Formula (4). Fang used linear regression to describe acceptability of air enthalpy at the selected pollution levels (including clean air). Acceptability function (2) was transformed by the authors using the Wargocki Equation (3) into the percentage of satisfied users (PD_Fang). It is presented in Figure 9 as $P D_{\text {FFang. }}$.

The results presented in Figure 9 are also correlated and have the same logarithmic dissatisfaction trend. The differences may result from a slightly different panel test method, but they also show that the dissatisfaction of users from indoor air quality for enthalpy above about $55 \mathrm{~kJ} / \mathrm{kg}$ is higher than the one derived from the thermal comfort model. The acceptability of indoor air quality under temperatures of 26 to $30{ }^{\circ} \mathrm{C}$ and $\mathrm{RH}=60 \%$ to $80 \%$ was studied by researchers from Hunan University [29]. The authors also confirmed a significant increase in dissatisfaction for high humidity. For example, for a temperature of $28{ }^{\circ} \mathrm{C}$ and $\mathrm{RH}$ humidity $80 \%$ (i.e., enthalpy of about $80 \mathrm{~kJ} / \mathrm{kg}$ ), they obtained a dissatisfaction value of $95 \%$, which is even greater than the value that would result from our experimental function, by up to $10 \%$. 


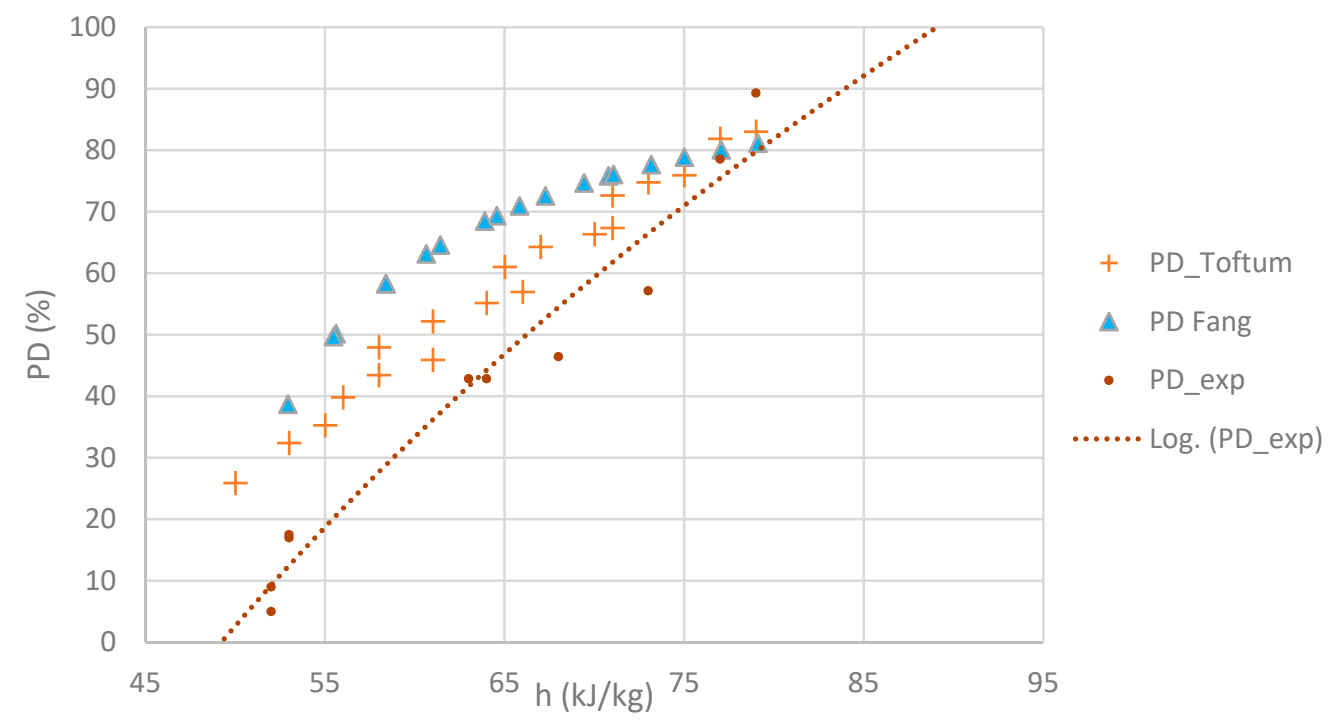

Figure 9. Comparison of experimental results of percentage dissatisfied in function of the air enthalpy (log.PD-exp) to the research results obtained by Fang (PD_Fang) [7] and Toftum (PD_Toftum) [15].

The authors believe that the proposed function, $P D=\mathrm{f}(\mathrm{h})$, is representative for the assessment of the indoor comfort of rooms equipped with a mechanical ventilation, such as that of nearly zero energy buildings, and is innovative in addressing the actual indoor environmental comfort for hot and humid conditions. As the calculation of enthalpy and the percentage of dissatisfaction on the basis of Relationship (9) is easier for non-experts than the calculation of PMV and PD from any thermal comfort model, the results obtained may find a wider practical application in the design of HVAC control BMS systems or the planning of heat and ventilation levels in existing buildings. There are examples in the literature of using enthalpy to control HVAC systems, especially when building users need to dry or humidify the indoor air [54]. For the estimation of indoor human comfort for mechanical ventilation eligibility, it can hardly be evaluated by indoor-outdoor temperature difference, only as used in conventional methods. The indoor temperature alone is obviously not sufficient to evaluate the indoor air enthalpy. A possible approach to address this problem is to use the spectrum of factors affecting the indoor condition, which was an example presented in reference [55]. The dual enthalpy control adds another enthalpy characteristic parameter sensor in the return air. The air with the lower enthalpy is brought into the conditioning section of the air handler. This is an efficient method of control that can be used with the Earth Air Heat Exchanger, as presented in Reference [56].

\section{Conclusions}

Numerous publications in which indoor environmental quality of buildings is assessed most often use the Fanger thermal model [57]. As shown in the article, under specific conditions such as increased humidity and temperature, this model will not give the correct results. It is proposed to evaluate the user satisfaction based on the air enthalpy that can be easily determined as a basic thermodynamic parameter. The authors presented the experimental curve of physical dependence (model) for predicting building occupants' dissatisfaction in hot and humid environments, $P D=\mathrm{f}(h)$. This relationship is primarily based on the Weber-Fechner law and the predicted percentage of dissatisfied users by air quality can be determined by means of air enthalpy $(h)$. The presented experiment has examined the indoor air quality (IAQ) perception of a panel group $(n=28)$ in the experimental NZEB building under ten environmental conditions (humid air but unpolluted). The obtained results indicate a much higher level of dissatisfaction of subjects' perception with indoor air quality in a warm and humid environment than that resulting from the Fanger thermal comfort model (TC). The authors suggest using the proposed model instead of the thermal one for the range of enthalpy between 50 and $90 \mathrm{~kJ} / \mathrm{kg}$ to assess the overall indoor environmental quality level of a building. Providing assessment with this 
method is simple and practical because enthalpy depends mainly on two parameters: temperature and humidity. Authors believe that the presented conclusions are important for building comfort prediction and modelling and prove the general thesis that in a hot indoor environment, air humidity (in practice, air enthalpy) is more important for an IAQ model than for the TC model.

Author Contributions: Conceptualisation, M.P. and K.K.; methodology, M.P.; software, M.P.; validation, M.P., K.K., M.F.-C. and K.N.; formal analysis, M.P.; investigation-test, M.F.-C., K.N.; resources, M.P. and M.F.-C.; data curation, M.P. and M.F.-C.; writing-original draft preparation, M.P.; writing-review and editing, M.P., K.K., M.F.-C., K.N.; visualisation, M.P.; supervision, M.P.; project administration, M.P.; funding acquisition, M.P. and M.F.-C. All authors have read and agreed to the published version of the manuscript.

Funding: This research received no external funding.

Conflicts of Interest: The authors declare no conflict of interest.

\section{Abbreviations}

The following abbreviations are used in this manuscript:

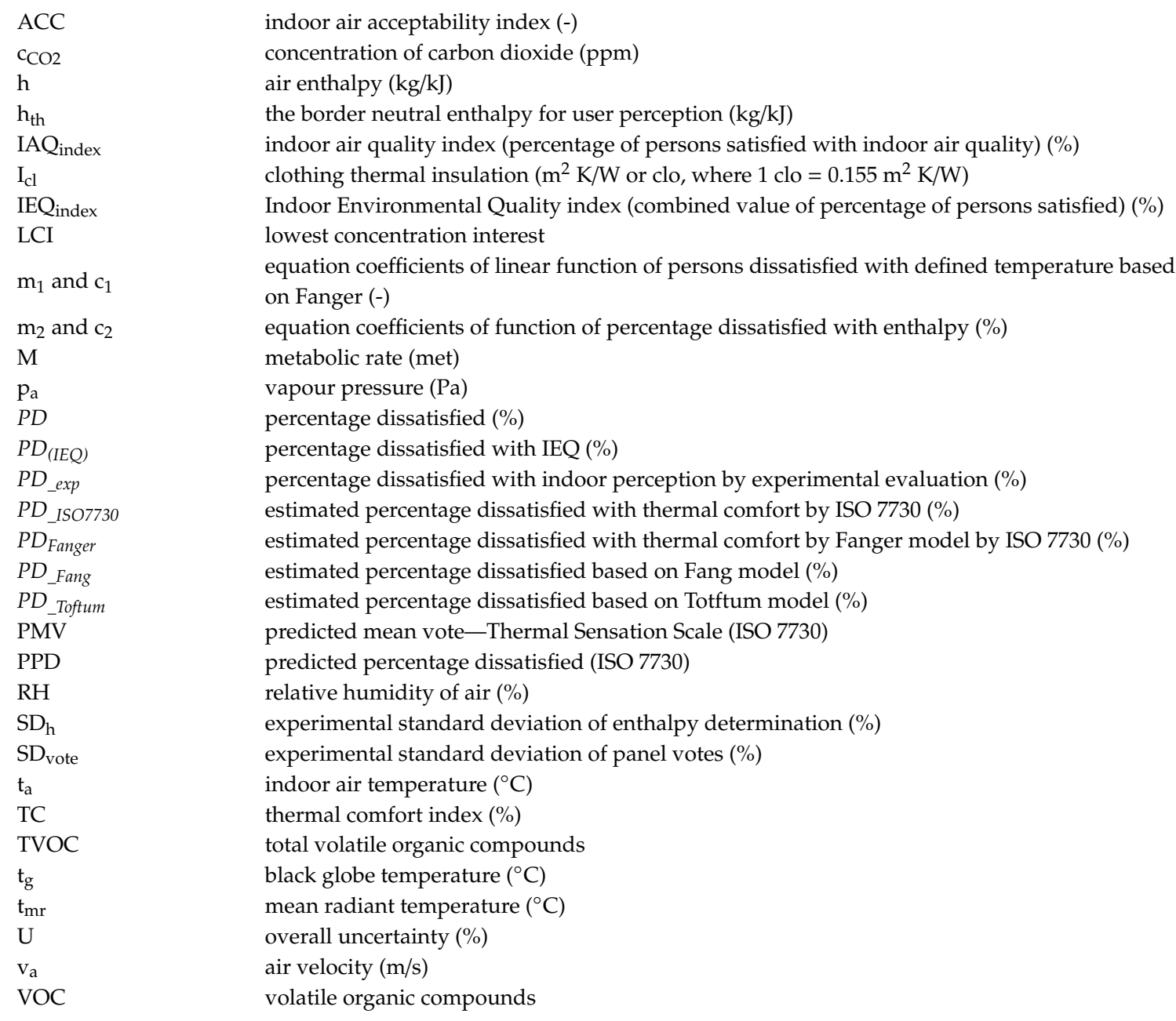

\section{References}

1. Yaglou, C.P. Sanitary Aspects of Air Conditioning. Am. J. Public Heal. Nations Heal. 1938, 28, $143-147$. [CrossRef]

2. Chu, C.M.; Jong, T.L. Enthalpy estimation for thermal comfort and energy saving in air conditioning system. Energy Convers. Manag. 2008, 49, 1620-1628. [CrossRef] 
3. Medeiros, C.M.; Baêta, F.D.C.; de Oliveira, R.F.; Tinôco, I.D.F.; Albino, L.F.; Cecon, P.R. Índice térmico ambiental de produtividade para frangos de corte. Rev. Bras. Eng. Agrícola e Ambient. 2005, 33, $19-27$. [CrossRef]

4. Chandra, S.; Fairey, P.W.; Bowen, A. Passive Cooling by Natural Ventilation: A Literature Review; Final Report, Task 1; Solar Energy Center: Cocoa, FL, USA, 1982; Volumes 1 and 2.

5. Buffington, D.E.; Collazo-Arocho, A.; Canton, G.H.; Pitt, D.; Thatcher, W.W.; Collier, R.J. Black Globe-Humidity Index (BGHI) as Comfort Equation for Dairy Cows. Trans. ASAE 1981, 24, 711-714. [CrossRef]

6. Piasecki, M.; Fedorczak-Cisak, M.; Furtak, M.; Biskupski, J. Experimental confirmation of the reliability of fanger's thermal comfort model-Case study of a near-zero energy building (NZEB) office building. Sustainbility 2019, 11, 2461. [CrossRef]

7. Fang, L.; Clausen, G.; Fanger, P.O. Impact of temperature and humidity on the perception of indoor air quality. Indoor Air 1998, 9, 193-201. [CrossRef]

8. Toftum, J. Human response to combined indoor environment exposures. Energy Build. 2002, 34, 601-606. [CrossRef]

9. Berglund, L. Thermal and non-Thermal Effects of Humidity on Comfort. J. Hum. -Environ. Syst. 1997, 97, 239-246. [CrossRef]

10. Lan, L.; Wargocki, P.; Wyon, D.P.; Lian, Z. Effects of thermal discomfort in an office on perceived air quality, SBS symptoms, physiological responses, and human performance. Indoor Air 2011, 21, 376-390. [CrossRef] [PubMed]

11. Piasecki, M.; Kostyrko, K. Indoor Environmental Quality Assessment Model IEQ Developed in ITB. Part 1. Choice of the Indoor Environmental Quality Sub-Component Models. Ciepłownictwo Ogrzew. Went. 2018, 49/6, 223-232. [CrossRef]

12. Lai, A.C.K.; Mui, K.W.; Wong, L.T.; Law, L.Y. An evaluation model for indoor environmental quality (IEQ) acceptance in residential buildings. Energy Build. 2009, 41, 930-936. [CrossRef]

13. Heinzerling, D.; Schiavon, S.; Webster, T.; Arens, E. Indoor environmental quality assessment models: A literature review and a proposed weighting and classification scheme. Build. Environ. 2013, 70, $210-222$. [CrossRef]

14. Piasecki, M. Practical implementation of the indoor environmental quality model for the assessment of nearly zero energy single-family building. Buildings 2019, 9, 214. [CrossRef]

15. Toftum, J.; Jørgensen, A.S.; Fanger, P.O. Upper limits of air humidity for preventing warm respiratory discomfort. Energy Build. 1998, 28, 15-23. [CrossRef]

16. Toftum, J.; Fanger, P.O. Air humidity requirements for human comfort. ASHRAE Trans. 1999, 105, 81-86.

17. Fanger, P. Calculation of Thermal Comfort, Introduction of a Basic Comfort Equation. ASHRAE Trans. 1967, 73, 1-20.

18. Fanger, P.O. Assessment of man's thermal comfort in practice. Occup. Environ. Med. 1973, 30, 313-324. [CrossRef] [PubMed]

19. ISO. ISO 7730: Ergonomics of the Thermal Environment Analytical Determination and Interpretation of Thermal Comfort Using Calculation of the PMV and PPD Indices and Local Thermal Comfort Criteria; International Organization for Standardization: Geneva, Switzerland, 2005.

20. Olesen, B.W.; Parsons, K.C. Introduction to thermal comfort standards and to the proposed new version of EN ISO 7730. Energy Build. 2002, 34, 537-548. [CrossRef]

21. Rohles, F.H., Jr.; Nevins, R.G. Thermal comfort: New directions and standards. Aerosp. Med. 1973, 44, 730-738.

22. Van Hoof, J. Forty years of Fanger's model of thermal comfort: Comfort for all? Indoor Air 2008, 18, $182-201$. [CrossRef]

23. Djongyang, N.; Tchinda, R.; Njomo, D. Thermal comfort: A review paper. Renew. Sustain. Energy Rev. 2010, 4, 2626-2640. [CrossRef]

24. Halawa, E.; Van Hoof, J. The adaptive approach to thermal comfort: A critical overview. Energy Build. 2012, 51, 101-110. [CrossRef]

25. Croitoru, C.; Nastase, I.; Bode, F.; Meslem, A.; Dogeanu, A. Thermal comfort models for indoor spaces and vehicles-Current capabilities and future perspectives. Renew. Sustain. Energy Rev. 2015, 44, 304-318. [CrossRef]

26. ANSI/ASHRAE. Standard 55-2017: Thermal Environmental Conditions for Human Occupancy; ASHRAE Inc.: Atlanta, GA, USA, 2017. 
27. Jin, L.; Zhang, Y.; Zhang, Z. Human responses to high humidity in elevated temperatures for people in hot-humid climates. Build. Environ. 2017, 114, 257-266. [CrossRef]

28. Kleber, M.; Wagner, A. Investigation of indoor thermal comfort in warm-humid conditions at a German climate test facility. Build. Environ. 2018, 128, 216-224. [CrossRef]

29. He, M.; Li, N.; He, Y.; He, D.; Wang, K. Influences of Temperature and Humidity on Perceived Air Quality with Radiant Panel Workstation. Procedia Eng. 2017, 205, 765-772. [CrossRef]

30. Jing, S.; Li, B.; Tan, M.; Liu, H. Impact of relative humidity on thermal comfort in a warm environment. Indoor Built Environ. 2013, 22, 4. [CrossRef]

31. Zhai, Y.; Zhang, Y.; Zhang, H.; Pasut, W.; Arens, E.; Meng, Q. Human comfort and perceived air quality in warm and humid environments with ceiling fans. Build. Environ. 2015, 90, 178-185. [CrossRef]

32. Buonocore, C.; De Vecchi, R.; Scalco, V.; Lamberts, R. Influence of relative air humidity and movement on human thermal perception in classrooms in a hot and humid climate. Build. Environ. 2018, 156, $233-242$. [CrossRef]

33. Rana, R.; Kusy, B.; Jurdak, R.; Wall, J.; Hu, W. Feasibility analysis of using humidex as an indoor thermal comfort predictor. Energy Build. 2013, 64, 17-25. [CrossRef]

34. Frontczak, M.; Wargocki, P. Literature survey on how different factors influence human comfort in indoor environments. Build. Environ. 2011, 46, 922-937. [CrossRef]

35. Kaczorek, D. Moisture buffering of multilayer internal wall assemblies at the micro scale: Experimental study and numerical modelling. Appl. Sci. 2019, 9, 3438. [CrossRef]

36. Nowoświat, A.; Skrzypczyk, J.; Krause, P.; Steidl, T.; Winkler-Skalna, A. Estimation of thermal transmittance based on temperature measurements with the application of perturbation numbers. Heat Mass Transf. 2018, 54, 1477-1489. [CrossRef]

37. Orlik-Kożdoń, B.; Steidl, T. Experimental and analytical determination of water vapour transmission properties of recyclable insulation material. Constr. Build. Mater. 2018, 192, 798-807. [CrossRef]

38. Gawin, D.J.; Koniorczyk, M.; Wieckowska, A.; Kossecka, E. Effect of moisture on hygrothermal and energy performance of a building with cellular concrete walls in climatic conditions of Poland. ASHRAE Trans. 2004, 110, 795-803.

39. Nicol, F. Adaptive thermal comfort standards in the hot-humid tropics. Energy Build. 2004, 36, $628-637$. [CrossRef]

40. Simonson, C.J. Moisture, thermal and ventilation performance of Tapanila ecological house. In VTT Tiedotteita-Valtion Teknillinen Tutkimuskeskus; VTT TIEDOTTEITA; Technical Research Centre of Finland: Espoo, Finland, 2000.

41. Dehaene, S. The neural basis of the Weber-Fechner law: A logarithmic mental number line. Trends Cogn. Sci. 2003, 12, 244-246. [CrossRef]

42. Goldstein, E.B.; Humphreys, G.W.; Shiffrar, M.; Yost, W.A. Blackwell Handbook of Sensation and Perception; Blackwell Publishing: Oxford, UK, 2008; ISBN 0631206841.

43. Jokl, M.V. A methodology for the comprehensive evaluation of the indoor climate based on human body response: Evaluation of the hygrothermal microclimate based on human psychology. Energy Build. 2014, 85, 458-463. [CrossRef]

44. CEN. EN 16798 Energy Performance of Buildings_Ventilation of Buildings-Part 1: Indoor Environmental input Parameters for Design and Assessment of Energy Performance of Buildings Addressing indoor Air Quality, Thermal Environment, Lighting and Acoustics; CEN: Brussels, Belgium, 2019.

45. Piasecki, M.; Kostyrko, K.B. Combined Model for IAQ Assessment: Part 1-Morphology of the Model and Selection of Substantial Air Quality Impact Sub-Models. Appl. Sci. 2019, 9, 3918. [CrossRef]

46. Piasecki, M.; Kostyrko, K.; Pykacz, S. Indoor environmental quality assessment: Part 1: Choice of the indoor environmental quality sub-component models. J. Build. Phys. 2017, 41, 264-289. [CrossRef]

47. Piasecki, M.; Kozicki, M.; Firlag, S.; Goljan, A.; Kostyrko, K. The approach of including TVOCs concentration in the indoor environmental quality model (IEQ)- case studies of BREEAM certified office buildings. Sustainbility 2018, 10, 3902. [CrossRef]

48. Piasecki, M.; Kostyrko, K.B. Indoor environmental quality assessment, part 2: Model reliability analysis. J. Build. Phys. 2018, 5, 1-28. [CrossRef]

49. Wang, J.; Wang, Z.; de Dear, R.; Luo, M.; Ghahramani, A.; Lin, B. The uncertainty of subjective thermal comfort measurement. Energy Build. 2018, 181, 38-49. [CrossRef] 
50. Alfano, A.; Palella, B.I.; Riccio, G. The role of measurement accuracy on the thermal environment assessment by means of PMV index. Build. Environ. 2011, 46, 1361-1369. [CrossRef]

51. Lira, I.; Taylor, J.R. Evaluating the Measurement Uncertainty: Fundamentals and Practical Guidance. Am. J. Phys. 2003, 71, 409-410. [CrossRef]

52. Ribeiro, A.S.; Alves e Sousa, J.; Cox, M.G.; Forbes, A.B.; Matias, L.C.; Martins, L.L. Uncertainty Analysis of Thermal Comfort Parameters. Int. J. Thermophys. 2015, 36, 2124-2149. [CrossRef]

53. Corless, R.M.; Gonnet, G.H.; Hare, D.E.G.; Jeffrey, D.J.; Knuth, D.E. On the Lambert W function. Adv. Comput. Math. 1996, 5, 329-359. [CrossRef]

54. Mazzei, P.; Minichiello, F.; Palma, D. HVAC dehumidification systems for thermal comfort: A critical review. Appl. Therm. Eng. 2005, 25, 677-707. [CrossRef]

55. Ali, M. Efficient indoor thermal comfort control via TSK adaptive control of HVAC systems. In Proceedings of the Conference Paper on "Computer, Control and Communication Engineering" (KIC4E-19), Kuala Lumpur, Malaysia, 23-25 September 2019.

56. Romanska-Zapala, A.; Bomberg, M.; Dechnik, M.; Fedorczak-Cisak, M.; Furtak, M. On Preheating of the Outdoor Ventilation Air. Energies 2020, 13, 15. [CrossRef]

57. Manfren, M.; Nastasi, B.; Piana, E.; Tronchin, L. On the link between energy performance of building and thermal comfort: An example. AIP Conf. Proc. 2019, 2123, 020066.

(C) 2020 by the authors. Licensee MDPI, Basel, Switzerland. This article is an open access article distributed under the terms and conditions of the Creative Commons Attribution (CC BY) license (http://creativecommons.org/licenses/by/4.0/). 